\title{
The Effect of Liquidity, Firm Size and Leverage on Financial Distress
}

\section{(Study on Mining Companies on The Indonesia Stock Exchange (IDX) in 2017-2019)}

\author{
Merisa Oktaria ${ }^{1,{ }^{*}}$ Maria Yanida ${ }^{2}$ Rinto Alexandro ${ }^{1}$ Tonich Tonich ${ }^{1}$ Windy Utami Putri ${ }^{1}$ \\ ${ }^{1}$ Department of Economics Education, Universitas Palangka Raya, Palangka Raya, Indonesia \\ ${ }^{2}$ Department of Accounting, STIE YBPK Palangka Raya, Indonesia \\ *Corresponding author. Email: merisa.oktaria@fkip.upr.ac.id
}

\begin{abstract}
The goal of this research is to shed light on the relationship between financial hardship and variables like liquidity, business size, and leverage. Multiple regression analysis was performed as part of the study's quantitative approach. The study was conducted on 22 mining companies with a research period of 2017-2019 and analyzed using SPSS version 23 software. The results showed that the liquidity variable proxied by current assets and the leverage variable proxied by the debt to equity ratio (DER) are known to have no effect on financial distress. While the size of the company has an effect on financial distress. The suggestions that can be given by the author are 1) so that investors should consider the factors that influence financial distress in making decisions, so that the decisions taken can be right in investing their funds and are able to avoid the risk of financial difficulties and 2) so that the management should pay attention to the condition again. companies, especially companies with potential financial difficulties, so that they can be used as a basis for taking corrective actions as soon as possible if they see indications that the company is experiencing financial distress.
\end{abstract}

Keywords: Liquidities, Firm size, Leverage, Financial distress.

\section{INTRODUCTION}

Using financial statement analysis, a company's health and future prospects can be forecast, including the likelihood of bankruptcy or what is known as financial distress [1]. In order to prevent the firm from going bankrupt, it is hoped that it would be possible to predict the company's future status and recognize the likelihood of financial difficulty early on. This will make it easier for decision makers to carry out financial restructuring so as not to become bankrupt.

Some of the indicators of approaching financial difficulties include a company's liquidity, business scale, and leverage. A company's ability to satisfy short-term obligations with its current assets is measured by its liquidity ratio. Currently, the ratio that is being used is the current ratio; the ratio of a company's total current assets to its total current liabilities. [2]. Current ratios are an indicator of how well a corporation can meet short-term financial obligations, which means that a higher current ratio indicates a lower likelihood of financial trouble.
The total value of a company's assets is used to calculate its size. Creditors look favorably on companies with big total assets since it is anticipated that the company will be able to pay off its debts in the future and so avoid financial trouble [3].

Financial hardship can also be predicted using leverage ratios in addition to liquidity and business size. When calculating a company's leverage ratio, we look at how much of the company's funding is provided by debt taken out from investors. Debt levels that are too high put the company in the danger zone of excessive leverage (extreme debt), where the company is unable to free itself from the burden of debt [4]. The more debt a company has, the more likely it is that it will not be able to pay off its debts when they are due, which could indicate that the firm will be in financial difficulties in the future.

Mining companies, especially coal, are currently in the spotlight in the business world due to the declining performance of coal companies, as seen from the decline in coal prices. Coal prices which decreased during the period 2011 to 2015 could not cover the company's 
operating costs. The high operating costs and the decline in coal prices made the company's revenue decline so that the company's profitability also decreased. Net income fell as revenues fell and expenses rose. One of the significant declines occurred in BSSR where profit for the year decreased by $44.1 \%$, namely in 2019 only Rp. $30,467,639$ compared to 2018 of Rp. 69,063,191 [5]. The decline in net profit was due to unfavorable global and sectoral economic conditions. This makes the company management must take more serious steps in managing the company. Company management must also be able to detect the company's financial status early on to ensure its long-term viability, and to prevent financial troubles.

The researchers are motivated to carry out research because of the aforementioned occurrence with the title "The Effect of Liquidity, Company Size and Leverage on Financial Distress Studies in Mining Companies on the Indonesia Stock Exchange (IDX) in 2017-2019".

Mining businesses on the Indonesian Stock Exchange (ISE) are the focus of this research. It examines how liquidity, company size, and leverage affect the financial difficulties of these companies, so that it will provide information to mining sector companies to understand the importance of knowing the company's condition in order to minimize the potential for bankruptcy.

Using data from the Indonesia Stock Exchange, this study tries to discover and analyze how liquidity affects financial distress in mining businesses. For the purpose of determining and analyzing the impact of firm size on financial distress in Indonesian mining enterprises, The Indonesian Stock Exchange (ISE) is a good place to study the impact of leverage on the financial difficulties of mining businesses. Mining businesses on the Indonesian Stock Exchange (ISE) are being studied to evaluate the impact of liquidity, company size, and debt on financial difficulty.

\section{METHOD}

This research model is based on the influence of the dependent variable Financial Distress (Y) with independent factors such as: Liquidity $\left(\mathrm{X}_{1}\right)$, Firm Size $\left(\mathrm{X}_{2}\right)$ and Leverage $\left(\mathrm{X}_{3}\right)$. The following is a conceptual framework for the research in Figure 1.

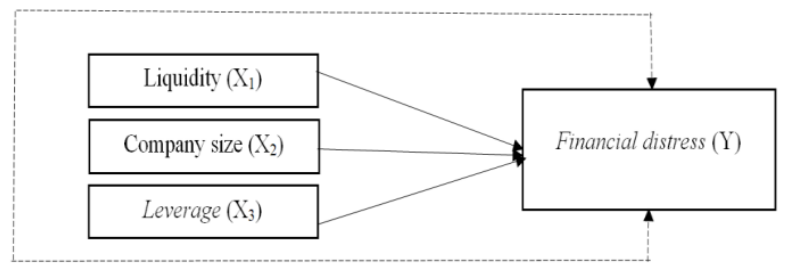

Information:

$\begin{array}{ll} & \text { : Partially } \\ & \text { : Simultaneously }\end{array}$

Figure 1.Research Model
Documentation of financial statements received from the IDX (Indonesia Stock Exchange) website was used to collect data for this study. Inferential statistics are used to analyze the data in this study. Using inferential statistics, a sample of data is analyzed and the results are extrapolated (inferred) to the population as a whole, as defined by Parametric and non-parametric inferential statistics can be separated into two categories [6]. Data from a normally distributed population, such as intervals and ratios, can be analyzed using parametric statistics. Non-parametric statistics, on the other hand, are used to examine data from a distribution-free population. Parametric statistics were employed in this investigation.

The data used in this study comes from annual financial reports listed on the IDX between 2017 and 2019, which can be acquired from www.idx.co.id. Companies that were listed on the Indonesia Stock Exchange during 2017-2019 and published their 20172019 annual reports and audit reports by the end of December are considered for sample purposes show in Table 1.

Independent variables are the variables that influence or are influenced by the dependent variable, or independent variable (Hartono, 2014). For this study, the following variables were utilized to measure independence: liquidity (X1). The current ratio is used as a measure of liquidity in this study. Measures how much of a company's existing assets may be used to meet its current liabilities.

$$
\text { Current Ratio }=\frac{\text { Current Asset }}{\text { Current Liabilities }}
$$

Firm Size $\left(\mathrm{X}_{2}\right)$. A company's size is the next independent variable to be considered. At the end of the period, the total assets of the company are used to determine the company's size.

$$
\text { Size }=\text { LN (Total Asset) }
$$

Leverage $\left(\mathrm{X}_{3}\right)$. Leverage ratio refers to the company's ability to use debt to finance assets and operational activities.

$$
\text { DER }=\frac{\text { Hutang Jk.Panjang }}{\text { Total Aset }}
$$

Dependent Variabel (Y). The independent variable has an effect on the dependent variable's value. Financial distress is the study's dependent variable.

Working Capital to Total Asset

$$
=\frac{\text { Working Capital }}{\text { Total Aset }} \times 100 \%
$$

Retained Earnings to Total Asset

$$
=\frac{\text { Retained Earning }}{\text { Total Aset }} \times 100 \%
$$


Earning Before Tax to Total Asset

$$
=\frac{\text { Earning before tax }}{\text { Total Aset }} \times 100 \%
$$

Market Value of Equity to Book Value of Liabilities

$$
=\frac{\text { Market Value of Equity }}{\text { Book Value Total Liabilities }} \times 100 \%
$$

Sales to Total Assets

$$
=\frac{\text { Sales }}{\text { Total Assets }} \times 100 \%
$$

Table 1. Sample

\begin{tabular}{|l|l|l|}
\hline No & \multicolumn{1}{|c|}{ Kode } & \multicolumn{1}{|c|}{ Nama Perusahaan } \\
\hline 1 & ADRO & Adaro Energy, Tbk \\
\hline 2 & ARII & Atlas Rerources, Tbk \\
\hline 3 & BUMI & Bumi Resources, Tbk \\
\hline 4 & BYAN & Bayan Resources, Tbk \\
\hline 5 & DEWA & Darma Herwa. Tbk \\
\hline 6 & GEMS & Golden Energy Mines, Tbk \\
\hline 7 & HRUM & Harum Energy, Tbk \\
\hline 8 & ITMG & Indo Tembaga Raya Megah, Tbk \\
\hline 9 & KKGI & Resource Alam Indonesia, Tbk \\
\hline 10 & MYOH & Samindo Resource, Tbk \\
\hline 11 & PTRO & Petrosea, Tbk \\
\hline 12 & TOBA & Toba Bara Sejahtera, Tbk \\
\hline 13 & ELSA & Elnusa, Tbk \\
\hline 14 & ESSA & Surya Eka Perkasa, Tbk \\
\hline 15 & MEDC & Medco Energy International, Tbk \\
\hline 16 & RUIS & $\begin{array}{l}\text { Radiant Utama International, } \\
\text { Tbk }\end{array}$ \\
\hline 17 & ANTM & Aneka Tambang, Tbk \\
\hline 18 & CITA & Cita Mineral Investindo, Tbk \\
\hline 19 & DKFT & Central Omega Resources, Tbk \\
\hline 20 & CTTH & Citatah, Tbk \\
\hline 21 & INCO & Vale Indonesia, Tbk \\
\hline 22 & ENRG & Energi Mega Persada, Tbk \\
\hline
\end{tabular}

\section{RESULTS \& DISSCUSION}

\subsection{Classic Assumption Test Results}

\subsubsection{Normality test}

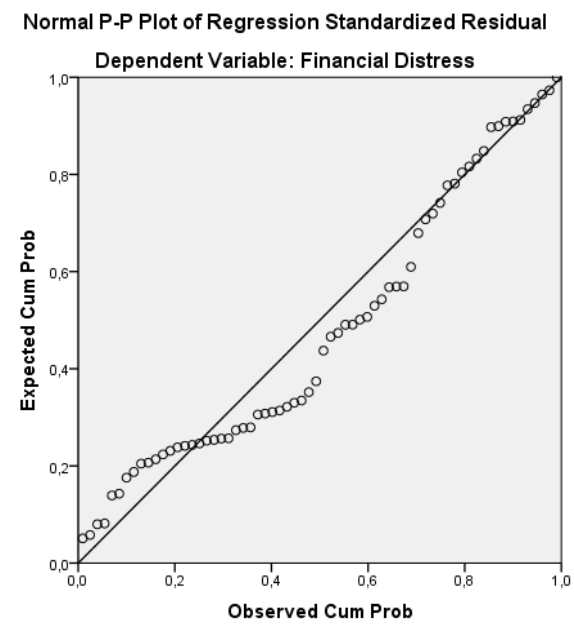

\begin{tabular}{|c|c|c|c|}
\hline Model & $\begin{array}{l}\text { Tolerance } \\
\text { Value }\end{array}$ & $\begin{array}{l}\text { VIF } \\
\text { Value }\end{array}$ & Description \\
\hline $\mathrm{X} 1$ & 0,803 & 1,254 & $\begin{array}{l}\text { Free } \\
\text { Multicollinearity }\end{array}$ \\
\hline$x 2$ & 0,993 & 1,007 & $\begin{array}{l}\text { Free } \\
\text { Multicollinearity }\end{array}$ \\
\hline X3 & 0,808 & 1,237 & $\begin{array}{l}\text { Free } \\
\text { Multicollinearity }\end{array}$ \\
\hline
\end{tabular}

Figure 2. P-P Plot

Table 2. The Result of Multicollinearity Test

Based on the Figure 2, it can be deduced that the data is normally distributed and satisfies the assumption of data normality because the data moves along a diagonal linear line.

\subsubsection{Multicollinearity Test}

This parameter does not confirm multicollinearity because, as shown in Table 2, there is no Tolerance value below 0.10 and no VIF value above 10 .

\subsubsection{Autocorrelation Test}

Based on the results of the autocorrelation test shown in Table 3, it is known that the D-W value is 1.789 . Because the value of $\mathrm{D}-\mathrm{W}$ lies between -2 to +2 , it can be concluded that in the analysis model there is no autocorrelation disorder.

\subsubsection{Heteroscedasticity Test}

Figure 3 shows that the dots are not arranged in a specific pattern, as can be observed. There is therefore no heteroscedasticity issue. 
Table 3. The Result of Auto Correlation

\begin{tabular}{|c|c|}
\hline Model & Durbin-Watson \\
\hline 1 & 1,789 \\
\hline \multicolumn{2}{c}{ Scatterplot }
\end{tabular}

Dependent Variable: Financial Distress

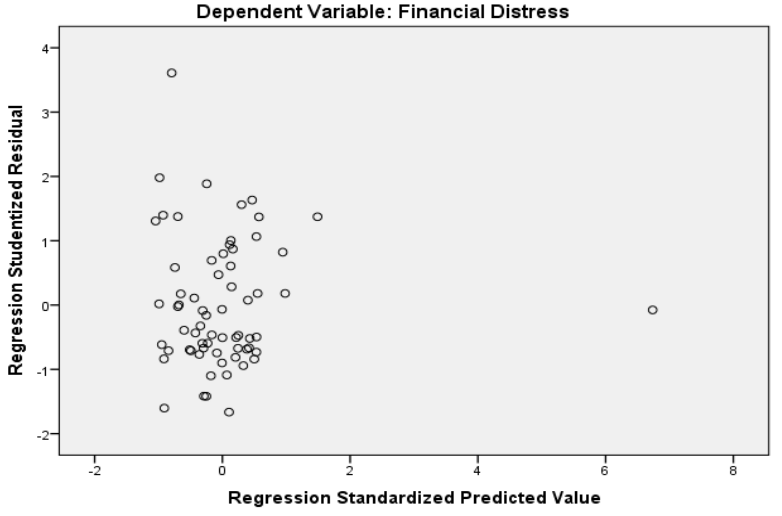

Figure 3. Scatterplot

Table 4 The Result of Hypothesis Test

\begin{tabular}{|l|c|c|l|}
\hline \multicolumn{1}{|c|}{ Hypothesis } & $\mathrm{t}$ & $\begin{array}{c}\mathrm{p} \\
\text { Value }\end{array}$ & \multicolumn{1}{|c|}{ Description } \\
\hline $\mathrm{H} 1$ & 0,377 & 0,708 & Rejected \\
\hline $\mathrm{H} 2$ & 0,208 & 0,036 & Accepted \\
\hline $\mathrm{H} 3$ & 0,602 & 0,549 & Rejected \\
\hline $\mathrm{H} 4$ & & 0,006 & Accepted \\
\hline
\end{tabular}

\subsubsection{Hypothesis test}

An independent variable partially affecting the dependent variable is tested using t-test. Based on the table above, the independent variable's effect on the dependent variable is:

Effect of Liquidity $\left(\mathrm{X}_{1}\right)$ on Financial Distress (Y). Table 4 shows that current ratio has a significant value of 0.708 as a liquidity proxy, according to the findings of the T-test. No effect on financial distress can be seen for current ratios with a significance greater than 0.05 . Since short-term obligations are classified as long-term debt when they cannot be paid in full by their due dates, the current ratio's ability to help a company's financial situation is hampered. Because of this, mining businesses' financial issues are not influenced by the company's current ratio, which is either high or low. On the other hand, organizations with low current ratios do not always have financial issues, while companies with high current ratios do.

Effect of Firm Size $\left(\mathrm{X}_{2}\right)$ on Financial Distress (Y). Company size was shown to be statistically significant at 0.036 , which falls below the threshold of 0.05 . A company's size has an impact on financial difficulties, according to the findings. The size of a firm is an indication of the company's total assets. The company's assets, if properly managed, can boost earnings. In addition, assets can produce additional income, such as through asset sales and purchases, sales in the context of expansion, asset pledging for financing solutions, and so on. According to signal theory, a corporation with a high amount of assets will communicate to investors that it has a strong financial footing (Nora, 2016). This means that companies that have a big number of assets are also wellcapitalized because their operating funding comes from assets rather than debt. It's possible to pay both short-term and long-term debts because of the company's rapid expansion and avoid financial difficulties.

Effect of Leverage $\left(\mathrm{X}_{3}\right)$ on Financial Distress (Y). The significant debt ratio is 0.549 based on the preceding $\mathrm{t}$ test. For as long as this significant value is greater than 0.05 , the DER ratio can be utilized as a leverage proxy without causing financial trouble. Leverage is used to calculate a company's debt-to-equity ratio. The debt-toequity ratio measures the debt-to-equity ratio. A high debt-to-equity ratio increases the risk of a company failing on long-term obligations. Because the company's overall debt can be covered by its own capital, the correlation between leverage and financial problems is minimal. The assets of the corporation have guaranteed the company's pledges. As a result, businesses will seek low-risk finance and improve management methods to maximize profits.

Effect of Liquidity, Firm Size and Leverage Simultaneously on Financial Distress (Y). In order to examine the impact of liquidity, business size and leverage on financial distress simultaneously, the F test was used. Table 4 shows that the fourth hypothesis has a p-value of 0.0006 , making it statistically significant. A combination of firm size and leverage has been found to cause financial trouble. On the basis of signal theory, high-quality organizations will purposefully communicate information about their financial ratios and size to the market in order to differentiate themselves from their competitors.

Current assets and current liabilities are shown in this ratio, which is called the "liquidity ratio." The current ratio is used as a proxy for the liquidity ratio in this research. Equivalently, it depicts the current assets to liabilities as a ratio. This means that the lower the current ratio figure, the lower the company's level of current assets relative to current liabilities. It is one of the elements that contribute to financial distress since the larger a firm is in relation to its financial health, the lower its risk of financial trouble. For example, a high debt ratio indicates a high level of borrowing, which might lead to delayed returns or even default. There is a greater chance that financial difficulty will occur.

Results show that the liquidity ratio can be used to identify financial problems before it occurs. The ability to meet short-term obligations is measured by a company's liquidity ratio [4]. Liquidity is a measure of a company's capacity to pay off its current obligations 
using its existing assets. If a corporation is able to meet its short-term commitments when they are due, it is considered liquid, however if the company is unable to meet its short-term obligations when they are due, it is considered illiquid. The current ratio is used as a proxy for liquidity in this study. The current ratio has little effect on financial distress, according to the results of statistical testing. Using the current ratio, this study found that the liquidity ratio variable had no impact on financial hardship, which is in accordance with previous research by [7]. Since short-term obligations are classified as longterm debt when they cannot be paid in full by their due dates, the current ratio's ability to help a company's financial situation is hampered. Profits can be increased by successfully managing the company's assets. The sale and acquisition of assets, the sale of assets in the context of expansion, asset pledging for financing solutions, and so on can all create additional income from assets. For example, according to signal theory, significant assets indicate that the company is financially strong [3]. In terms of capital, a large company size signifies that the company has large assets, which means that the company has a solid capital structure because the company's operational financing is derived from its assets rather than from borrowing money. Financial difficulty was found to be influenced in part by the company's size. According to research undertaken by [8] and [9], a company's size has an impact on its ability to meet its financial obligations.

Research conducted by [10] demonstrates that company size has no effect on financial difficulty. However, this contradicts the findings of [10]. There are three metrics used to calculate the company's leverage ratio. When a firm uses too much debt, it falls into the category of excessive leverage, which means that the company is heavily in debt and cannot easily get out of it [4]. Because of their high debt levels, companies may be unable to satisfy their financial responsibilities in the future. The debt ratio can be used to measure a company's debt level. Deficiency ratio is the percentage of debt to total assets. The higher the debt-to-assets ratio, the greater the company's debt-to-capitalization ratio. There is a direct correlation between debt ratio and the likelihood of financial distress. An increase in the debtto-income ratio increases the likelihood of financial hardship. The partial debt to equity ratio (DER), used as a leverage proxy, appears to have little effect on financial difficulty. Money isn't a problem for leverage, according to this research and the findings of [2] and [10]. According to [11], [12], leverage has an impact on financial distress, which contradicts the findings of [11].

Leverage is used to calculate a company's debt-toequity ratio. The debt-to-equity ratio measures the debtto-equity ratio. A high debt-to-equity ratio increases the risk of a company failing on long-term obligations. Because the company's total debt can be covered by its own capital, this finding indicates to financial statement users that the link between leverage and financial difficulty is minor. A guarantee has been made by the company's assets in order to ensure the company's commitments. Companies who are looking to raise money will look for low-risk sources of funding, and they'll strengthen their management practices in order to maximize revenues. 4) The term "financial distress" refers to a pre-bankruptcy or liquidation downturn in financial situations. According to [13], financial hardship occurs when a company's financial situation deteriorates. Financial distress is influenced by a number of factors, including liquidity, business size, and leverage, all of which have a substantial impact.

Liquidity, profitability, leverage, and activity ratios all have an impact on financial hardship, which is consistent with studies undertaken by [14]. In addition, [15] shows that liquidity, operating capacity, and company size all have an impact on financial distress simultaneously. On the basis of signal theory, highquality organizations will purposefully communicate information about their financial ratios and size to the market in order to differentiate themselves from their competitors. Current assets and current liabilities are shown in this ratio, which is called the "liquidity ratio." The current ratio is used as a proxy for the liquidity ratio in this research. Equivalently, it depicts the current assets to liabilities as a ratio. In other words, a lower current ratio shows that a company's current assets are less than its current liabilities. It is one of the elements that contribute to financial distress since the larger a firm is in relation to its financial health, the lower its risk of financial trouble. For example, a high debt ratio indicates a high level of borrowing, which might lead to delayed returns or even default. There is a greater chance that financial difficulty will occur.

\section{CONCLUSION}

The following conclusions can be derived from the outcomes of research and discussion: Financial distress is not affected by the liquidity ratio. Due to the fact that companies with high current ratio values don't always avoid financial troubles, while organizations with low current ratios don't inevitably go into financial difficulty. Second, the size of a firm has a considerable impact on the likelihood of financial hardship. Corporations with substantial total assets are much less likely to go bankrupt than are those with little total assets. Debt-to-equity ratio (DER) leverage has no effect on financial hardship. This is due to the fact that the corporation has enough money to cover all of its debts. In other words, the company's capital has served as a guarantee for the debt it has accrued. Financial distress is affected by all three independent variables simultaneously (liquidity, company size, and leverage). 


\section{REFERENCES}

[1] F. Margaretha, Dasar Dasar Manajemen Keuangan. Jakarta: Dian Rakyat, 2014.

[2] N. L. M. A. Widhiari and N. K. L. A. Merkusiwati, "Pengaruh Rasio Likuiditas, Leverage, Operating Capacity, dan Sales Growth Terhadap Financial Distress," E-Jurnal Akunt. Univ. Udayana, vol. 11, no. 2, pp. 456-469, 2015.

[3] A. R. Nora, "Pengaruh Financial Indicators, Ukuran Perusahaan, dan Kepemilikan Institusional Terhadap Financial Distress," J. STIE Perbanas Surabaya, 2016.

[4] I. Fahmi, Analisis Kinerja Keuangan. Bandung: Alfabeta, 2014.

[5] F. U. Ulfah, "Baramulti (BSSR) Bukukan Penurunan Laba hingga 56, 5 Persen,” 2020. https://market.bisnis.com/read/20200318/192/1214 923/baramulti-bssr-bukukan-penurunan-labahingga-565-persen (accessed Apr. 14, 2021).

[6] Sugiyono, Metode Penelitian Kombinasi (Mix Methods). Bandung: Alfabeta, 2015.

[7] M. L. FIRDIANA, "PENGARUH CURRENT RATIO, RETURN ON ASSET, UKURAN PERUSAHAAN DAN SALES GROWTH TERHADAP FINANCIAL DISTRESS. Undergraduate thesis," STIE PERBANAS SURABAYA, 2016.

[8] A. Putri and N. Merkusiwati, "Pengaruh Mekanisme Corporate Governance, Likuiditas, Leverage, Dan Ukuran Perusahaan Pada Financial Distress," E-Jurnal Akunt., vol. 7, no. 1, pp. 93106, 2014.

[9] D. Susilawati, "Pengaruh Pofitabilitas,Ukuran Perusahaan, Dan Leverage Terhadap Financial Distress Pada Perusahaan Yang Terdaftar Di Bursa Efek Indonesia," J. Akunt., pp. 208-215, 2017.

[10] W. P. Rahayu and D. Sopian, Pengaruh Rasio Keuangan Dan Ukuran Perusahaan Terhadap Financial Distress (Studi Empiris Pada Perusahaan Food And Beverage Di Bursa Efek Indonesia). 2017.

[11] M. A. Hidayat and W. Meiranto, "Prediksi Financial Distress Perusahaan Manufaktur di Indonesia. Diponegoro," J. Account., vol. 3, no. 3, pp. 1-11, 2014.

[12] C. E. B. Simanjuntak, F. T. Krist, and W. Aminah, "Pengaruh Rasio Keuangan Terhadap Financial Distress," eProceedings Manag., vol. 4, no. 2, 2017.

[13] T. N. S. S. Tukan, "Analisis Faktor Penjelas Financial Distress Pada Perusahaan Manufaktur Di
Bursa Efek Indonesia," Universitas Negeri Yogyakarta, 2018.

[14] O. E. Hanifah, "Pengaruh Struktur Corporate Governance dan Financial Indicators terhadap Kondisi Financial distress Distress (Studi pada Perusahaan Manufaktur yang Terdaftar di Bursa Efek Indonesia Tahun 2008-2010)," Universitas Diponegoro, 2013.

[15] W. Setyowati and N. R. Sari, "Pengaruh Likuiditas, Operating Capacity, Ukuran Perusahaan dan Pertumbuhan Penjualan Terhadap Financial Distress," J. Magisma, vol. 3, no. 2, pp. 135-146, 2019. 